\title{
INFLUENCE OF HPFRCC COMPRESSIVE STRENGTH AND CONFINEMENT ON CONCRETE
}

\author{
Dinesh KUMAR, Mykolas DAUGEVIČIUS* \\ Vilnius Gediminas Technical University, Sauletekio al., LT-10223, Vilnius, Lithuania
}

Received 26 October 2018; accepted 16 January 2019

\begin{abstract}
The article analyses behavior of compressed concrete cylinders which were strengthened with external high performance fiber reinforced cementitious composite (HPFRCC) layer. Two different HPFRCC materials were used for the strengthening, which differed in fiber type. Two different types of loading were applied as well. The load was transferred through the whole cross section of the strengthened element and through the core - internal concrete. Loading through the whole cross section allows to validate the mixture law. Loading through the internal concrete allows to investigate the confinement effect. Comparison of theoretically calculated and experimental strength shows that mixture law and confinement effect is valid. Confinement by HPFRCC allowed to increase the strength of concrete about 4 times, but the ultimate strain remains similar. The strength of elements loaded through the whole surface has increased much more and additionally the ultimate strain has increased too.
\end{abstract}

Keywords: concrete, strengthening, HPFRCC, confinement, compressive strength.

\section{Introduction}

Generally strengthening of columns is created by providing an additional confinement or incorporating a new layer which intercepts a part of the external load. The confinement is usually created as a thin layer of high performance material carbon fiber reinforced polymer (CFRP), PBO-FRCM (p-Phenylene Benzobis Oxazole fiber reinforced cementitious mortar), steel reinforced polymer (SRP), self-compacting concrete (SCC), textile reinforced concrete (TRC), steel-reinforced grout (SRG), and confinement usually increases the strength of internal concrete. The additional layer which intercepts the part of external load can be made from steel profiles, concrete or masonry. Concreting or creating masonry layer can decrease the existing space. Thus, it is better to create a new thinner layer from high strength concrete. Shrinkage of concrete can change effectiveness of the strengthening. The loading area consists of strengthened element area and new added layer area. After shrinkage of new layer, the area of transferred external load can move to the previous strengthened element area. In this case the external layer loses capacity to intercept the external load and begins to provide the confinement. So instead of concrete, high per- formance fiber cementitious composite (HPFRCC) with good tensile resistance should be used. Also shrinkage of concrete can influence the strength of confined structure elements. The research (Vincent \& Ozbakkaloglu, 2015) shows that due to shrinkage, increment of strains in CFRP and concrete changes and strength of confined concrete can slightly decrease.

Most of researches related with strengthening of RC columns use strengthening with CFRP, basalt fibers reinforced polymer, textile reinforced concrete, Ferro cement, HPFRCC. The external load transferring area depends on the thickness of the external layer and the strengthening method. Strengthening with CFRP provides the new thin external layer and CFRP does not intercept the compressive stresses, so just the confinement effect is evaluated. While strengthening with fiber reinforced polymer, textile reinforced concrete or ferro cement, the thickness of external layer varies from 0.2 to $11.5 \mathrm{~mm}$ (Raffoul et al., 2017; AL-Gemeel \& Zhuge, 2018; Shi-ping, Xiang-qian, \& Yun-tao, 2018; Ghalieh, Awwad, Saad, Khatib, \& Mabsout, 2017; Thermou \& Hajirasouliha, 2018; De Caso y Basalo, Matta, \& Nanni, 2012; R. Ortlepp \& S. Ortlepp,

*Corresponding author. E-mail: mykolas.daugevicius@vgtu.lt 
2017). Strengthening with reinforced fine-grained concrete layer (R. Ortlepp \& S. Ortlepp, 2017) or HPFRCC (Daugevičius \& Valivonis, 2013, 2017) allows evaluating compressive resistance of external layer. However, the review shows that usually the confinement effect is evaluated (Thermou \& Hajirasouliha, 2018; De Caso y Basalo et al., 2012; Cascardi, Longo, Micelli, \& Aiello, 2017; Trapko, 2013; Huang, Sun, Yan, \& Zhu, 2015; Zhou, Bi, Wang, \& Zhang, 2016; Colajanni, De Domenico, Recupero, \& Spinella, 2014; Napoli \& Realfonzo, 2016; Chastre \& Silva, 2010; Tamuzs, Tepfers, \& Sparnins, 2006).

Resistance due to provided confinement or direct interception of compressive stresses can differ in times, because the compressive strength of concrete is much bigger than tensile. Most equations which evaluate the confinement effect require the lateral strain (Thermou \& Hajirasouliha, 2018; De Caso y Basalo et al., 2012; Cascardi et al., 2017; Huang et al., 2015; Colajanni et al., 2014; Napoli \& Realfonzo, 2016; Chastre \& Silva, 2010; Tamuzs et al., 2006; Ombres, 2014; Campione, La Mendola, Monaco, Valenza, \& Fiore, 2015; Cascardi, Aiello, \& Triantafillou, 2017) or strength (Trapko, 2013, 2014; Zhou et al., 2016; Wei \& $\mathrm{Wu}, 2014)$ of external material. Evaluation of direct interception of compressive stresses requires compatibility of strains. Without compatibility, the strength of materials cannot be fully used. Therefore, the concrete materials are suitable for interception of compressive stresses. The objective of this research is to determine how the strength of a strengthened compressed concrete changes when the external load is being transferred through a different cross-section area. Different loading determines which strengthening effect should be evaluated. Loading of the core determines the evaluation of the confinement effect. Loading of the whole section determines the evaluation of the interception of compressive stresses.

\section{Specimens, materials and testing}

Totally 18 cylindrical standard concrete specimens were produced. Cylindrical specimens were divided into five groups (Table 1). The first group contains 6 control concrete specimens $\mathrm{C} 1$; $\mathrm{C} 2$; $\mathrm{C} 3$; $\mathrm{C} 4$; $\mathrm{C} 5$; 6 . In the second group the specimens $\mathrm{C} 7$; $\mathrm{C}$; C9 were strengthened with high strength concrete designated as HPFRCC1. In this group the specimens were loaded through the internal concrete core. In the third group the specimens $\mathrm{C} 10$; C11; C12 were also strengthened with high strength concrete designated as HPFRCC1, but they were loaded through the whole section. The specimens C13; C14; $\mathrm{C} 15$ of fourth group were strengthened with high strength concrete designated as HPFRCC2 and loaded through the internal concrete core. The specimens C16; C17; C18 of fifth group were also strengthened with high strength concrete designated as HPFRCC2, but loaded through the whole section. The age of all elements at time of strengthening was 28 days. The approximate diameter of strengthened elements was $190 \mathrm{~mm}$.
High strength concrete HPFRCC1 and HPFRCC2 used for strengthening had differed just by a fiber type. The percentage of special cement, sand, water, super plasticizer was almost the same (see Table 2). Material HPFRCC1 contains polyvinyl alcohol fibers and material HPFRCC2 brass coated steel fibers.

The concrete constituent of cement, sand, water and stone filler are shown in Table 3. The cone sediment of

Table 1. Description of specimens

\begin{tabular}{|c|c|c|c|c|c|}
\hline $\begin{array}{l}\text { Speci- } \\
\text { men } \\
\text { name }\end{array}$ & $\begin{array}{c}\text { Diame- } \\
\text { ter } \\
{[\mathrm{mm}]}\end{array}$ & $\begin{array}{l}\text { Height } \\
{[\mathrm{mm}]}\end{array}$ & $\begin{array}{l}\text { Loading } \\
\text { type }\end{array}$ & $\begin{array}{l}\text { Strength- } \\
\text { ening ma- } \\
\text { terial }\end{array}$ & Description \\
\hline $\mathrm{C} 1$ & 149.83 & 295.67 & \multirow{6}{*}{$\begin{array}{l}\text { Full } \\
\text { section }\end{array}$} & \multirow{6}{*}{-} & \multirow{6}{*}{$\begin{array}{l}\text { Control } \\
\text { specimens }\end{array}$} \\
\hline $\mathrm{C} 2$ & 149.83 & 301.33 & & & \\
\hline C3 & 149.5 & 299.67 & & & \\
\hline $\mathrm{C} 4$ & 149.67 & 301.33 & & & \\
\hline $\mathrm{C} 5$ & 149.5 & 299 & & & \\
\hline C6 & 149.17 & 299.67 & & & \\
\hline $\mathrm{C} 7$ & 190.33 & 298.33 & \multirow{3}{*}{$\begin{array}{l}\text { Core } \\
\text { section }\end{array}$} & \multirow{6}{*}{ HPFRCC1 } & \multirow{6}{*}{$\begin{array}{l}\text { Layer } \\
\text { thickness } \\
\mathrm{t}=20 \mathrm{~mm}\end{array}$} \\
\hline $\mathrm{C} 8$ & 190 & 295.67 & & & \\
\hline C9 & 189 & 299.67 & & & \\
\hline $\mathrm{C} 10$ & 188.33 & 298.67 & \multirow{3}{*}{$\begin{array}{l}\text { Full } \\
\text { section }\end{array}$} & & \\
\hline $\mathrm{C} 11$ & 190.67 & 299 & & & \\
\hline $\mathrm{C} 12$ & 188.67 & 297 & & & \\
\hline $\mathrm{C} 13$ & 190.33 & 300 & \multirow{3}{*}{$\begin{array}{l}\text { Core } \\
\text { section }\end{array}$} & \multirow{6}{*}{ HPFRCC2 } & \multirow{6}{*}{$\begin{array}{l}\text { Layer } \\
\text { thickness } \\
\mathrm{t}=20 \mathrm{~mm}\end{array}$} \\
\hline C14 & 188.83 & 298.33 & & & \\
\hline $\mathrm{C} 15$ & 189 & 297.67 & & & \\
\hline $\mathrm{C} 16$ & 189 & 295.67 & \multirow{3}{*}{$\begin{array}{l}\text { Full } \\
\text { section }\end{array}$} & & \\
\hline $\mathrm{C} 17$ & 188.83 & 301.67 & & & \\
\hline $\mathrm{C} 18$ & 189.33 & 297.33 & & & \\
\hline
\end{tabular}

Table 2. Composition of high strength concrete

\begin{tabular}{|l|c|c|}
\hline $\begin{array}{l}\text { High strength concrete } \\
\text { constituent }\end{array}$ & $\begin{array}{c}\text { Percentage } \\
\text { by weight, \%, } \\
\text { HPFRCC1 }\end{array}$ & $\begin{array}{c}\text { Percentage by } \\
\text { weight, \%, } \\
\text { HPFRCC2 }\end{array}$ \\
\hline $\begin{array}{l}\text { Cement and pozzolanic } \\
\text { additives }\end{array}$ & 43.7 & 42.27 \\
\hline Sand and microfillers & 47.86 & 46.30 \\
\hline Water & 6.66 & 6.44 \\
\hline Superplasticizer & 0.74 & 0.72 \\
\hline Other additives & 0.29 & 0.29 \\
\hline Brass coated steel fibers & - & 3.98 \\
\hline Polyvinyl alcohol fibers & 0.75 & - \\
\hline
\end{tabular}

Table 3. Composition of concrete

\begin{tabular}{|l|c|}
\hline \multicolumn{1}{|c|}{ Concrete constituent } & Weight $\mathrm{kg} / \mathrm{m}^{3}$ \\
\hline Cement & 83.19 \\
\hline Sand & 532.74 \\
\hline Water & 99.12 \\
\hline Stone Filler & 1338.1 \\
\hline
\end{tabular}


concrete is $16 \mathrm{~cm}$ and the $\mathrm{W} / \mathrm{C}$ ratio is 1.19 . The authors use a low strength concrete in order to investigate the effect of confinement provided by HPFRCC material. A low strength concrete characterizes by early plasticity and this makes it easier to see the effect of confinement.

The surfaces of strengthened specimens were treated with high pressure water jet. The high-pressure water jet was used to remove the small sand particles of concrete and to make the surface of it rough. After the strengthening the new layer of high strength concrete has perfect bonding. The treated surface is shown in Figure 1a. Before the strengthening surfaces of concrete specimens were moistened and then the specimens were placed into

a)

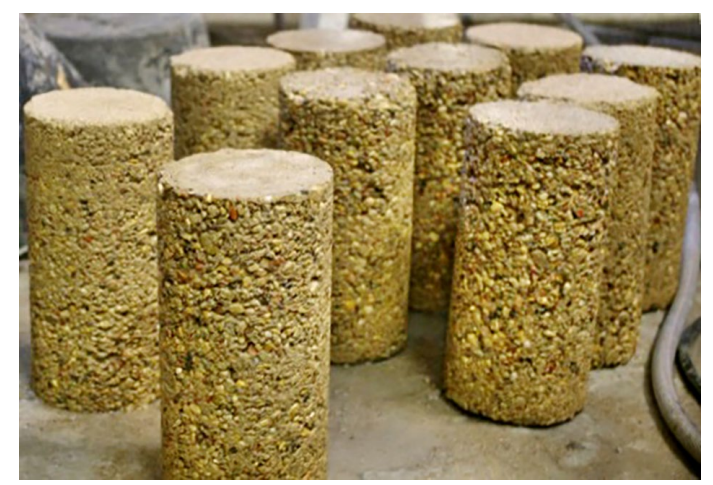

b)

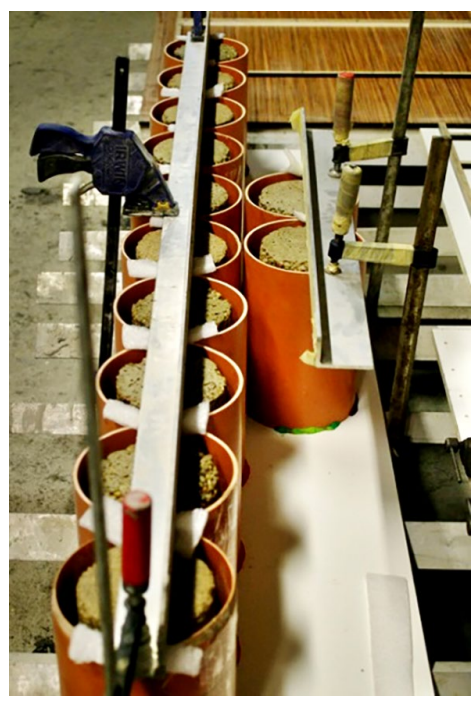

Figure 1. Preparation of specimens: (a) - surface after treatment with high pressure water jet;

(b) - specimens in the moulds the moulds. The gap between internal concrete and mould edge was $20 \mathrm{~mm}$. The tops of the specimens were supported by a longitudinal metal plate (see Figure 1b) and the high strength concrete was poured into the free space of mould. The top support prevents moving of internal concrete core.

In order to validate the mixture law, the strengthened specimens were loaded through the whole surface. In order to examine the effect of confinement, the strengthened specimens were loaded through the internal concrete core. The age of control specimens at time of testing was 43 days. Testing of strengthened elements started at age of 44 days. Loading scheme is shown in Figure 2.

Particular mechanical parameters of concrete and high strength concrete are needed for theoretical approach. These parameters are shown in Tables 4 and 5. Different types of material specimens were produced. Small prisms for compression and briquettes for tension were made from high strength concrete. Cubes and cylinder were made from ordinary concrete. Compressive strength $\left(f_{c}\right)$ a)
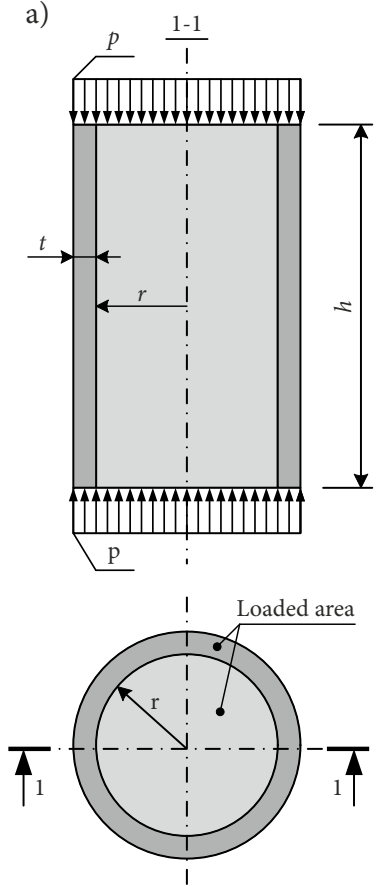

b)
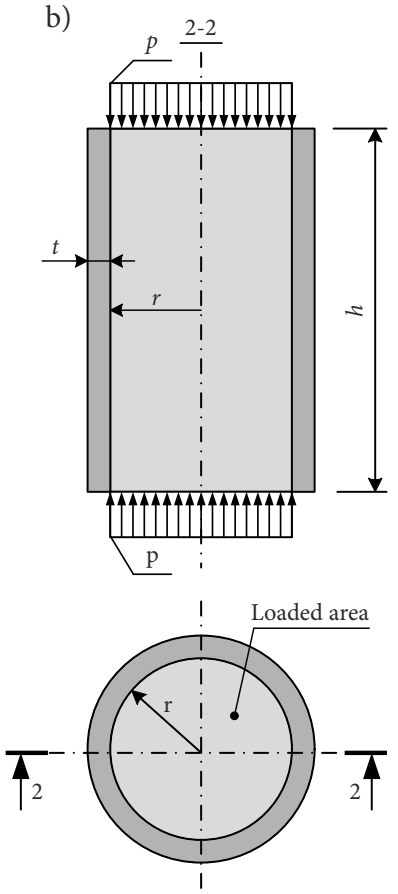

Figure 2. Loading of strengthened specimens: (a) - loading through the whole surface; (b) - loading through the internal concrete core. Here designations $p$ - external load pressure; $t$ - thickness of external jacket; $r$ - radius of internal concrete cylinder; $h$ - height of the specimen

Table 4. Material mechanical parameters obtained from compression test

\begin{tabular}{|l|l|c|c|c|c|c|c|}
\hline $\begin{array}{c}\text { Specimen } \\
\text { (quantity of specimen) }\end{array}$ & Material & $\begin{array}{c}f_{c}[\mathrm{MPa}] \\
(7 \text { days of } \\
\text { HPFRCC) }\end{array}$ & $\begin{array}{c}\text { Coef. of } \\
\text { variation [\%] }\end{array}$ & $\begin{array}{c}f_{c}[\mathrm{MPa}] \\
(28 \text { days of } \\
\text { HPFRCC) }\end{array}$ & $\begin{array}{c}\text { Coef. of } \\
\text { variation [\%] }\end{array}$ & $\begin{array}{c}E_{c}[\mathrm{GPa}] \\
(7 \mathrm{days} \text { of } \\
\text { HPFRCC) }\end{array}$ & $\begin{array}{c}E_{c}[\mathrm{GPa}] \\
(28 \text { days of } \\
\text { HPFRCC) }\end{array}$ \\
\hline Cubes $150 \times 150 \times 150(3)$ & Concrete & - & - & 4.48 & 3.88 & - & - \\
\hline Cylinders $\varnothing 150 \times 300(6)$ & Concrete & - & - & 3.6 & 15.82 & - & 15.24 \\
\hline Prisms $40 \times 40 \times 160(3)$ & HPFRCC1 & 77.63 & 4.18 & 90.97 & 8.47 & 41.5 & 38.85 \\
\hline Prisms $40 \times 40 \times 160(3)$ & HPFRCC2 & 84.68 & 2.44 & 93.88 & 6.6 & 43.77 & 46.01 \\
\hline
\end{tabular}


Table 5. Mechanical parameters of HPFRCC material obtained from flexural and tensile test

\begin{tabular}{|c|c|c|c|c|c|c|c|c|c|}
\hline $\begin{array}{c}\text { Specimen } \\
\text { (quantity of specimen) }\end{array}$ & Material & $\begin{array}{c}f_{c c l}[\mathrm{MPa}] \\
7 \text { days }\end{array}$ & $\begin{array}{c}\text { Coef. of } \\
\text { variation } \\
{[\%]}\end{array}$ & $\begin{array}{c}f_{c c l}[\mathrm{MPa}] \\
28 \text { days }\end{array}$ & $\begin{array}{c}\text { Coef. of } \\
\text { variation } \\
{[\%]}\end{array}$ & $\begin{array}{c}f_{c c t}[\mathrm{MPa}] \\
7 \text { days }\end{array}$ & $\begin{array}{c}\text { Coef. of } \\
\text { variation } \\
{[\%]}\end{array}$ & $\begin{array}{c}f_{c c t}[\mathrm{MPa}] \\
28 \text { days }\end{array}$ & $\begin{array}{c}\text { Coef. of } \\
\text { variation } \\
{[\%]}\end{array}$ \\
\hline Briquettes (3) & HPFRCC1 & - & - & - & - & 5.43 & 4.74 & 5.76 & 6.87 \\
\hline Briquettes (3) & HPFRCC2 & - & - & - & - & 5.4 & 13.05 & 7.61 & 23.49 \\
\hline Prisms $40 \times 40 \times 160(3)$ & HPFRCC1 & 6.63 & 14.2 & 6.01 & 7.1 & - & - & - & - \\
\hline Prisms $40 \times 40 \times 160(3)$ & HPFRCC2 & 9.87 & 15.01 & 14.13 & 5.87 & - & - & - & - \\
\hline
\end{tabular}

a)

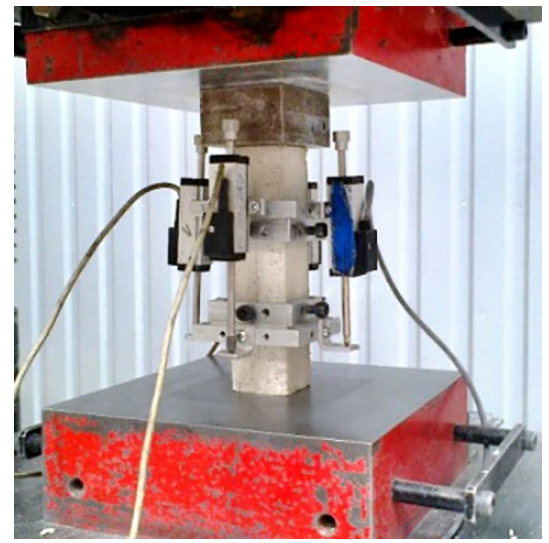

b)

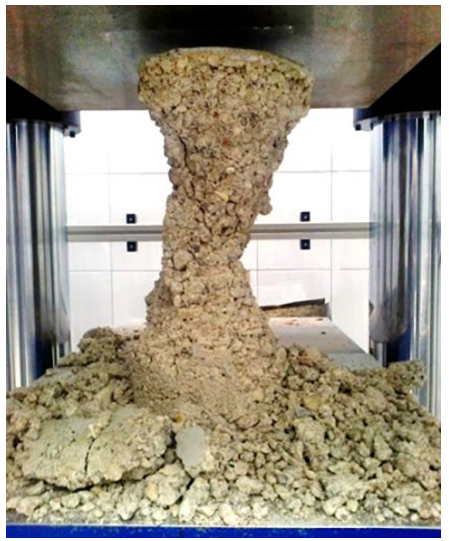

c)

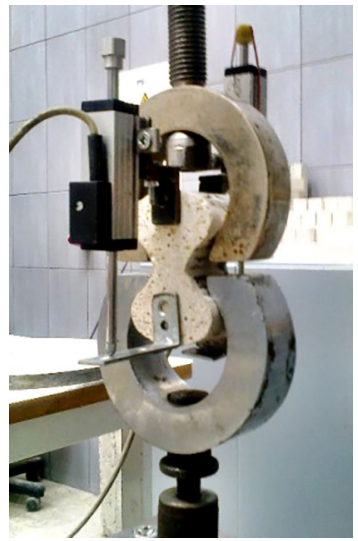

Figure 3. Material specimens during test: (a) - high strength concrete prism; (b) - concrete cylinder; (c) - briquette specimen at direct tension test

and modulus of elasticity $\left(E_{c}\right)$ of each material were obtained during the compressive test (Figure $3 \mathrm{a}$ and Figure $3 \mathrm{~b})$. Tensile strength $\left(f_{c c t}\right)$ of high strength concrete was obtained from direct tensile test (Figure 3c). Also, flexural strength $\left(f_{c c l}\right)$ was obtained for high strength concrete material.

\section{Calculation}

The concrete cylinder after strengthening becomes a composite element. The ultimate deformations must be taken into account. An ordinary concrete has a higher plasticity (see Figure 5b). Then the ultimate strain of HPFRCC concrete is reached while the concrete is working plastically. Thus, ultimate strength of each material can be evaluated. When the load is applied on the whole surface, the strength of strengthened element can be calculated:

$$
f_{\text {c.c. } V}=f_{c} \cdot V_{c}+f_{H . c} \cdot V_{H . c},
$$

where $f_{\text {c.c. } V}$ - the compressive strength of composite element evaluating the mixture law, $f_{c}$ - the compressive strength of concrete material, $f_{H . c}$ - the compressive strength of high strength concrete, $V_{c}$ - the volume ratio of concrete material, $V_{H . c}-$ the volume ratio of high strength concrete material. If height of each material layer is equal, then volume ratios:

$$
\begin{aligned}
& V_{c}=\frac{A_{c}}{A_{t o t}} ; \\
& V_{H . c}=\frac{A_{H . c}}{A_{t o t}},
\end{aligned}
$$

where $A_{c}$ - the cross section of the concrete material, $A_{H . c^{-}}$ the cross section of the high strength concrete material, $A_{\text {tot }}$ - the total cross section of the strengthened element.

When the load is transferred through the internal core - concrete, the confinement effect should be evaluated. Strength of strengthened element can be calculated:

$$
f_{c . c . C}=f_{c}+\left(\frac{1-v}{v}\right) \cdot f_{l},
$$

where $f_{\text {c.c.C }}$ - the compressive strength of composite element evaluating the confinement effect, $v$ - Poisson ratio (0.2), of internal concrete material, $f_{l}$ - the lateral strength of internal concrete material. The lateral strength is predicted from the equilibrium of internal forces (Figure 4):

$$
F_{l}=F_{H . t} .
$$

For the rectangular stress distribution block (Figure $4 \mathrm{a})$ :

$$
f_{l} \cdot r=f_{H . t} \cdot t ; f_{l}=\frac{f_{H . t} \cdot t}{r} \text {. }
$$
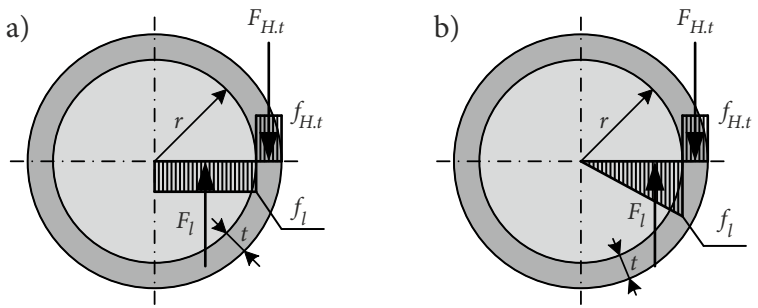

Figure 4. Internal stresses and forces of confined element: (a) - evaluations of rectangular distribution block; (b) - evaluation of triangular distribution block 
For the triangular stress distribution block (Figure $4 \mathrm{~b}$ ):

$$
f_{l} \cdot \frac{1}{2} \cdot r=f_{H . t} \cdot t ; f_{l}=\frac{f_{H . t} \cdot t \cdot 2}{r} .
$$

\section{Results}

Experimentally and theoretically predicted resistance of strengthened elements is presented in Table 6. Confinement of concrete by HPFRCC material had increased the compressed strength of concrete by 4 times. It was experimentally proved that type of fiber also influences the increment of strength. The specimens with steel fibers had resisted a higher load than specimens with polyvinyl alcohol fibers. Tensile properties of HPFRCC2 material are better than of HPFRCC1 (see Table 5). The steel fibers possess higher tensile strength than polyvinyl alcohol fibers, thus steel fibers provide higher fracture energy. Strength of confined specimens with HPFRCC2 material was about $6 \%$ bigger than of specimens with HPFRCC1 material. Strength of fully loaded specimens had increased much more. At this time, the increment was influenced by a compressive strength of jacket. The compressive strength of HPFRCC2 material was higher than for HPFRCC1 material. Thus, strength of strengthened elements with HPFRCC2 material was about 19\% higher than for specimens with HPFRCC1 material.

When the load is transferred through the internal concrete core, the concrete core and external HPFRCC jacket experience different stress-strain state. Internal concrete core works for compression and external jacket for tension. Bond of internal concrete with the external HPFRCC material jacket transfers compressive action for external jacket. Therefore, the expansion of internal concrete creates the tensile stresses in the external jacket and confined specimen fails then the tensile strength of the external jacket is reached. Such state is evaluated in Equation (4) and calculated results are presented in Table 6. However, the different distribution of internal (horizontal direction) stresses was evaluated. Evaluation of triangular distribution block (Figure $4 \mathrm{~b}$ ) had increased the lateral stress of confined concrete up to two times and this influenced better calculated result.

Then the load is transferred through the whole section, both materials experience the compression action. The mixture law which is applied to the composite elements may be evaluated. Nevertheless, the compatibility of strains should be taken into account. The ultimate strains when the concrete material or the HPFRCC material crush are similar to each other (Figure $5 \mathrm{a}$ and Figure $5 \mathrm{~b}$ ). This allows to evaluate the full compressive strength of each material in Equation (1). Good agreement of calculated result proves the mixture law.

Recorded compressive strains of the confined specimens show that the compressive strength of the external HPFRCC material was not fully utilized (see Figure 5c). These specimens failed then the tensile strength of external jacket material was reached. At the maximal load, external jacket loses its tensile strength and break off through the all height (see Figure 6a and Figure 6c). Specimens with the fully loaded section failed due to the crushing of internal and external concrete (see Figure $6 \mathrm{~b}$ and Figure $6 \mathrm{~d}$ ). Loading through the whole section allows to utilize the full compressive strength of each material.

In Figure 5a S1 \& S3 the test result of prisms $(40 \times 40 \times 160)$ specimens with polyvinyl alcohol fibers after $7 \& 28$ days of curing is presented. S2 \& S4 represent the test result of prisms $(40 \times 40 \times 160)$ specimens with brass coated steel fibers after $7 \& 28$ days of curing. Figure $5 b$ $\mathrm{C} 1$; 2 ; C3; C4; C5; C6 represents the testing of concrete cylinder. The specimens C7; C8; C9 \& C10; C11; C12 represent test result of samples with polyvinyl alcohol fibers in Figure 5c, Figure 5d. The specimens C13; C14; C15 \& $\mathrm{C} 16$; $\mathrm{C} 17$; $\mathrm{C} 18$ represent test result of specimens with brass coated steel fibers in Figure 5c, Figure 5d.

Table 6. Experimental and calculated results of strengthened elements

\begin{tabular}{|c|c|c|c|c|c|c|c|c|}
\hline $\begin{array}{l}\text { Sample } \\
\text { name }\end{array}$ & Jacket & Loading & $\mathrm{F}_{\max }[\mathrm{kN}]$ & $\begin{array}{l}\text { Exp. Stress } \\
{[\mathrm{MPa}]}\end{array}$ & $\begin{array}{l}\text { Avg. of exp. } \\
\text { Stress [MPa] }\end{array}$ & $\begin{array}{c}\text { Coef. of } \\
\text { variation [\%] }\end{array}$ & $\begin{array}{l}\text { Calc. Stress } \\
\text { (eq. 5) }[\mathrm{MPa}]\end{array}$ & $\begin{array}{l}\text { Calc. Stress } \\
\text { (eq. 6) }[\mathrm{MPa}]\end{array}$ \\
\hline $\mathrm{C} 7$ & \multirow{6}{*}{ HPFRCC1 } & \multirow{3}{*}{$\begin{array}{l}\text { Core } \\
\text { section }\end{array}$} & 240 & 13.59 & \multirow{3}{*}{14.19} & \multirow{3}{*}{4.87} & \multirow{3}{*}{9.4} & \multirow{3}{*}{15.19} \\
\hline $\mathrm{C} 8$ & & & 248.1 & 14.05 & & & & \\
\hline C9 & & & 264 & 14.95 & & & & \\
\hline $\mathrm{C} 10$ & & \multirow{3}{*}{$\begin{array}{l}\text { Full } \\
\text { section }\end{array}$} & 912.4 & 32.77 & \multirow{3}{*}{32.68} & \multirow{3}{*}{1.52} & \multirow{3}{*}{\multicolumn{2}{|c|}{31.11}} \\
\hline $\mathrm{C} 11$ & & & 917.6 & 32.15 & & & & \\
\hline $\mathrm{C} 12$ & & & 925.6 & 33.13 & & & & \\
\hline $\mathrm{C} 13$ & \multirow{6}{*}{ HPFRCC2 } & \multirow{3}{*}{$\begin{array}{l}\text { Core } \\
\text { section }\end{array}$} & 400.3 & $22.66^{*}$ & \multirow{3}{*}{15.08} & \multirow{3}{*}{0.844} & \multirow{3}{*}{9.36} & \multirow{3}{*}{15.11} \\
\hline $\mathrm{C} 14$ & & & 264.8 & 14.99 & & & & \\
\hline $\mathrm{C} 15$ & & & 267.9 & 15.17 & & & & \\
\hline $\mathrm{C} 16$ & & \multirow{3}{*}{$\begin{array}{l}\text { Full } \\
\text { section }\end{array}$} & 1123.4 & 40.06 & \multirow{3}{*}{38.95} & \multirow{3}{*}{4.05} & \multirow{3}{*}{\multicolumn{2}{|c|}{33.68}} \\
\hline $\mathrm{C} 17$ & & & 1059 & 37.83 & & & & \\
\hline $\mathrm{C} 18$ & & & 748.2 & $26.59^{*}$ & & & & \\
\hline
\end{tabular}

Note: ${ }^{*}$ - due to high variation values were neglected. 

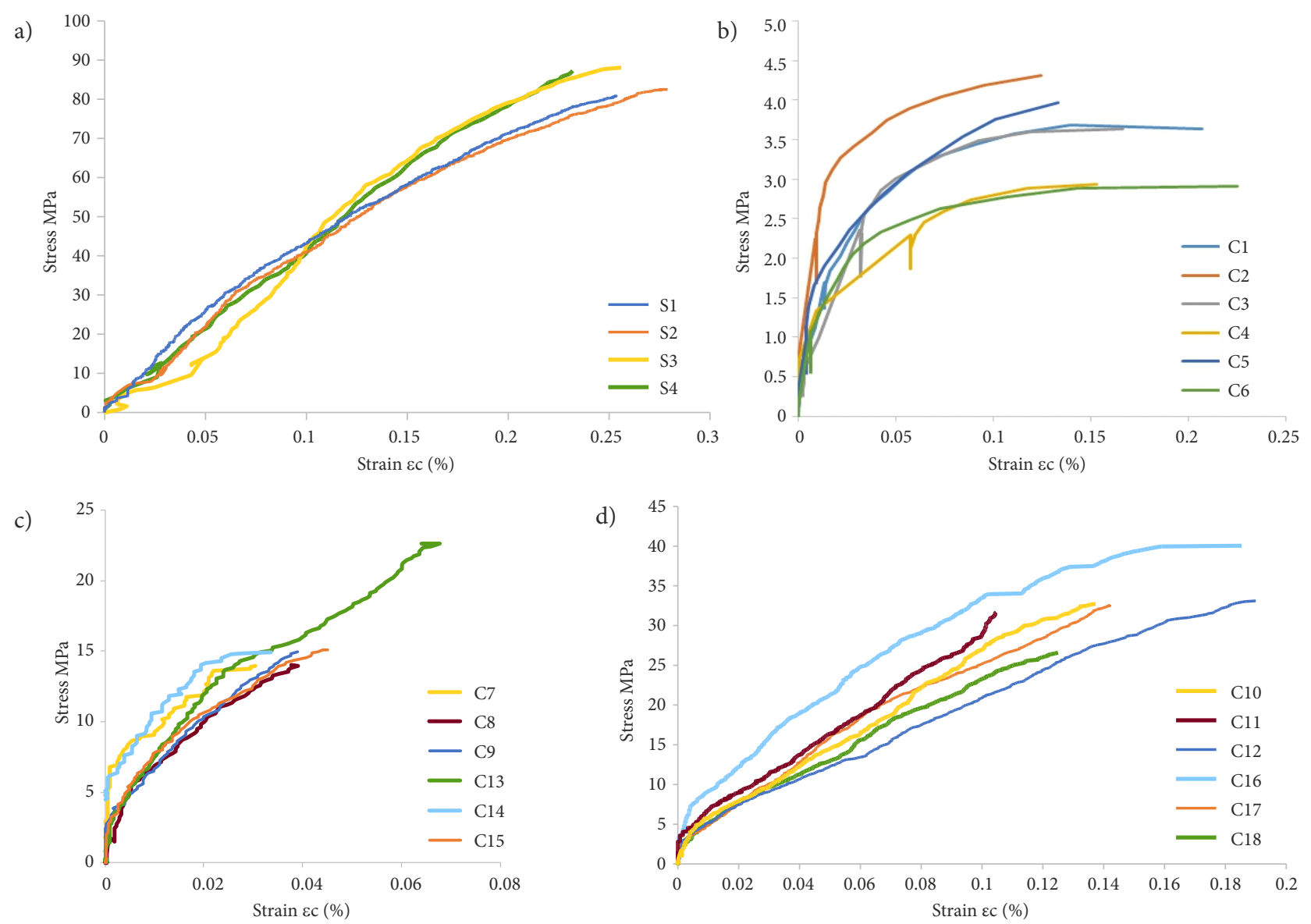

Figure 5. Graphs of experimental test: (a) - prisms made of HPFRCC1 and HPFRCC2 material;

(b) - concrete cylinders; (c) - confined specimens; (d) - specimens loaded on whole surface

a)

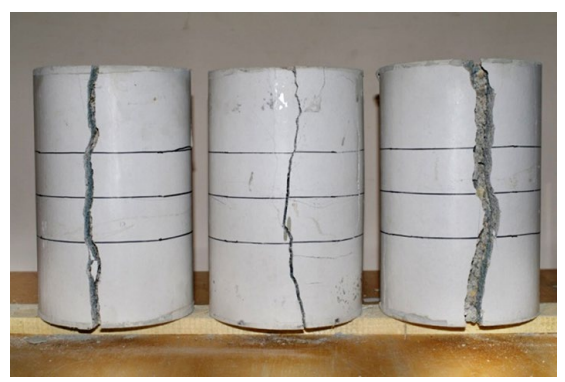

c)

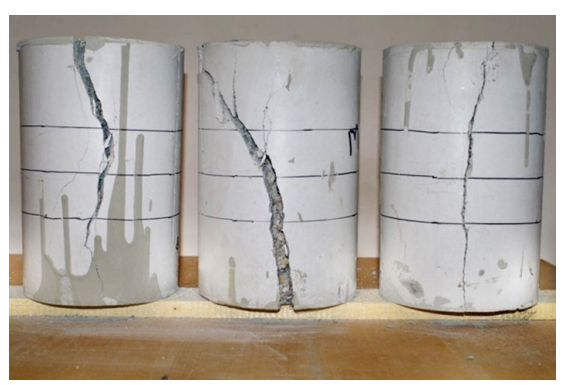

b)

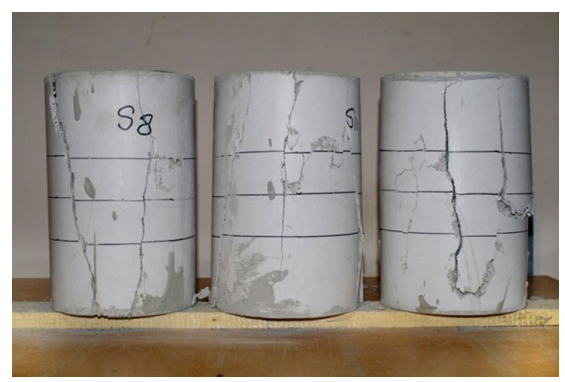

d)

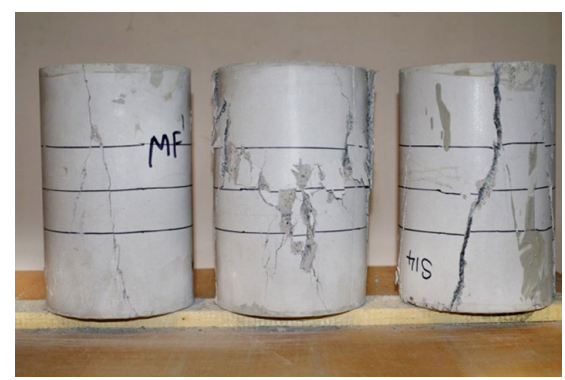

Figure 6. Specimens after experimental test: (a) - specimens confined with HPFRCC1 material; (b) - specimens strengthened with HPFRCC1 material; (c) - specimens confined with HPFRCC2 material; (d) - specimens strengthened with HPFRCC2 material

\section{Conclusions}

The strength of confined elements increased up to four times, the strength of confined concrete with HPFRCC material (polyvinyl alcohol fibers) increased up to four times, and the strength of specimens with brass coated steel fibers increased up to 4.2 times. The strength of fully loaded elements increased from 9.1 to 10.8 times respectively. The best increase of strength was gained with the 
HPFRCC material which contains brass coated steel fibers. Compressive and tensile tests of HPFRCC material with brass coated steel fibers showed the higher values. Especially tensile strength after 28 days increased up to $41 \%$. This can be related with the better bond strength of steel fibers. HPFRCC material specimens with polyvinyl alcohol fibers failed in tensile test immediately after the crack opening. The polyvinyl alcohol fibers do not provide sufficient tensile hardening and softening.

Calculation of resistance of fully loaded strengthened elements proved validation of mixture law equation. Calculated resistance for specimens with polyvinyl alcohol fibers HPFRCC material varied by $4.8 \%$ and resistance for specimens with brass coated steel fibers varied by $13.5 \%$. Calculated resistance of confined elements shows better results when the triangular lateral stress distribution block is used. For the specimens with polyvinyl alcohol fibers HPFRCC material resistance varied by $7 \%$ and resistance for specimens with brass coated steel fibers varied by $0.2 \%$. By the evaluation of a rectangular block the resistance varied from $33.8 \%$ to $38 \%$ respectively.

\section{Acknowledgements}

The authors are grateful to Hibeton for material supply and technical support.

\section{References}

AL-Gemeel, A. N., \& Zhuge, Y. (2018). Experimental investigation of textile reinforced engineered cementitious composite (ECC) for square concrete column confinement. Construction and Building Materials, 174, 594-602.

https://doi.org/10.1016/j.conbuildmat.2018.04.161

Campione, G., La Mendola, L., Monaco, A., Valenza, A., \& Fiore, V. (2015). Behavior in compression of concrete cylinders externally wrapped with basalt fibers. Composites Part B: Engineering, 69, 507-586.

https://doi.org/10.1016/j.compositesb.2014.10.008

Cascardi, A., Aiello, M. A., \& Triantafillou, T. (2017). Analysisoriented model for concrete and masonry confined with fiber reinforced mortar. Materials and Structures, 50(4), 202. https://doi.org/10.1617/s11527-017-1072-0

Cascardi, A., Longo, F., Micelli, F., \& Aiello, M. A. (2017). Compressive strength of confined column with Fiber Reinforced Mortar (FRM): New design-oriented-models. Construction and Building Materials, 156, 387-401.

https://doi.org/10.1016/j.conbuildmat.2017.09.004

Chastre, C., \& Silva, M. A. G. (2010). Monotonic axial behavior and modelling of RC circular columns confined with CFRP. Engineering Structures, 32, 2268-2277.

https://doi.org/10.1016/j.engstruct.2010.04.001

Colajanni, P., De Domenico, F., Recupero, A., \& Spinella, N. (2014). Concrete columns confined with fibre reinforced cementitious mortars: Experimentation and modelling. Construction and Building Materials, 52, 375-384.

https://doi.org/10.1016/j.conbuildmat.2013.11.048

Daugevičius, M., \& Valivonis, J. (2013). Axially loaded concrete and reinforced concrete elements strengthened with HPFRCC. Paper presented at the Fiber concrete, September 12-13. Prague, Czech Republic.
Daugevičius, M., \& Valivonis, J. (2017). Concrete and reinforced concrete elements strengthened with HPFRCC. KSCE Journal of Civil Engineering, 22(8), 2961-2969.

https://doi.org/10.1007/s12205-017-0044-9

De Caso y Basalo, F., Matta, F., \& Nanni, A. (2012). Fiber reinforced cement-based composite system for concrete confinement. Construction and Building Materials, 32, 55-65. https://doi.org/10.1016/j.conbuildmat.2010.12.063

Ghalieh, L., Awwad, E., Saad, G., Khatib, H., \& Mabsout, M. (2017). Concrete columns wrapped with hemp fiber reinforced polymer - an experimental study. Procedia Engineering, 200, 440-447. https://doi.org/10.1016/j.proeng.2017.07.062

Huang, L., Sun, X., Yan, L., \& Zhu, D. (2015). Compressive behavior of concrete confined with GFRP tubes and steel spirals. Polymers, 7, 851-875. https://doi.org/10.3390/polym7050851

Napoli, A., \& Realfonzo, R. (2016). Compressive behavior of concrete confined by SRP wraps. Construction and Building Materials, 127, 993-1008.

https://doi.org/10.1016/j.conbuildmat.2016.01.055

Ombres, L. (2014). Concrete confinement with a cement based high strength composite material. Composite Structures, 109, 294-304. https://doi.org/10.1016/j.compstruct.2013.10.037

Ortlepp, R., \& Ortlepp, S. (2017). Textile reinforced concrete for strengthening of RC columns: A contribution to resource conservation through the preservation of structures. Construction and Building Materials, 132, 150-160. https://doi.org/10.1016/j.conbuildmat.2016.11.133

Raffoul, S., Garcia, R., Escolano-Margarit, D., Guadagnini, M., Hajirasouliha, I., \& Pilakoutas, K. (2017). Behaviour of unconfined and FRP-confined rubberised concrete in axial compression. Construction and Building Materials, 147, 388-397. https://doi.org/10.1016/j.conbuildmat.2017.04.175

Shi-ping, Y., Xiang-qian, H., \& Yun-tao, H. (2018). Study on the compression performance of small eccentric degradation columns strengthened with TRC in a chloride environment. Construction and Building Materials, 176, 50-59. https://doi.org/10.1016/j.conbuildmat.2018.05.003

Tamuzs, V., Tepfers, R., \& Sparnins, E. (2006). Behavior of concrete cylinders confined by a carbon composite 2 . Prediction of strength. Mechanics of Composite Materials, 42(2), 165-178. https://doi.org/10.1007/s11029-006-0022-7

Thermou, G. E., \& Hajirasouliha, I. (2018). Compressive behaviour of concrete columns confined with steel-reinforced grout jackets. Composites Part B: Engineering, 138, 222-231. https://doi.org/10.1016/j.compositesb.2017.11.041

Trapko, T. (2013). Stress-strain model for FRCM confined concrete elements. Composites Part B: Engineering, 45, 1351-1359. https://doi.org/10.1016/j.compositesb.2012.07.001

Trapko, T. (2014). Confined concrete elements with PBO-FRCM composites. Construction and Building Materials, 73, 332-338. https://doi.org/10.1016/j.conbuildmat.2014.09.055

Vincent, T., \& Ozbakkaloglu, T. (2015). Influence of shrinkage on compressive behavior of concrete-filled FRP tubes: An experimental study on interface gap effect. Construction and Building Materials, 75, 144-156.

https://doi.org/10.1016/j.conbuildmat.2014.10.038

Wei, Y., \& Wu, Y. F. (2014). Compression behavior of concrete columns confined by high strength steel wire. Construction and Building Materials, 54, 443-453.

https://doi.org/10.1016/j.conbuildmat.2013.12.083

Zhou, J., Bi, F., Wang, Z., \& Zhang, J. (2016). Experimental investigation of size effect on mechanical properties of carbon fiber reinforced polymer (CFRP) confined concrete circular specimens. Construction and Building Materials, 127, 643652. https://doi.org/10.1016/j.conbuildmat.2016.10.039 